\title{
Punica granatum: A New Host of Bipolaris spicifera in Morocco
}

\author{
Oumama Kadri*, Rachid Benkirane, Amina Ouazzani Touhami, and Allal Douira*
}

Laboratoire de Botanique et de Protection des Plantes, Université Ibn Tofail, Faculté des Sciences, Kénitra, Morocco

Received: February 12, 2011 / Accepted: May 8, 2011

\begin{abstract}
Uring March 2009 in the public gardens and the University of Sciences of Kenitra city (Morocco), $60 \%$ of leaves of 100 plants of pomegranate (Punica granatum L. 'Nana') presented foliar lesions that affecting the aesthetic appearance of this ornamental plant. Bipolaris spicifera was isolated from ten necrotic lesions of $\mathbf{2 5}$ leaves. The artificial inoculation of the healthy leaves of three plants of Punica granatum L. 'Nana' by conidial suspension of the pathogen induced the same lesions to that observed in nature. The diseased foliar surface and the total number of diseased leaves 30 days after inoculation with $B$. spicifera conidial suspension were $37.5 \%$ and 78 . Conidia production of $B$. spicifera on inoculated leaves was $0.81 \times 10^{5}$ spore $\mathrm{cm}^{-2}$ and the fungus was re-isolated from lesions on inoculated plants. This is the first report of B. spicifera on pomegranate in Morocco.
\end{abstract}

Keywords: Punica granatum L.'Nana', Bipolaris spicifera, Lesions, Inoculation.

*Corresponding authors: douiraallal@hotmail.com \& ok_ouma@ hotmail.com.

\section{Introduction}

Pomegranate (Punica granatum L.) is a fruitful ornamental tree in the tropical and subtropical areas of the world, including the Mediterranean Basin and Asia. Several varieties are generally associated with this species. Punica granatum L. 'Nana' is a dwarf variety more valuable for its numerous small flowers and long flowering period (Jianzhu et al., 2003).

In March 2009, the survey in the public and the University of Sciences gardens of Kenitra city (Morocco) showed that $60 \%$ of leaves of 100 plants of Punica granatum L. 'Nana' presented foliar lesions affecting the aesthetic appearance of this ornamental plant. At the time of attacking, temperatures varied between 10 and $25^{\circ} \mathrm{C}$ (average of $17.5^{\circ} \mathrm{C}$ ) and the rainfall for the month was $19 \mathrm{~mm}$. The necrotic lesions developed on the periphery and in the middle of leaves were sometimes numerous, often circular with dark brown color and measuring 1 to 4 $\mathrm{mm}$ in diameter. Later, the midst of these lesions becomes more clear and surrounded by a border of dark purple (Fig. 1). This was the first time that these symptoms were observed on Punica granatum L. 'Nana'. 


\section{Material and Methods}

Twenty five leaves showing necrotic lesions were collected from 5 plants of Punica granatum L. 'Nana'. Leaves with lesions were cut in small fragments, washed with water, disinfected in alcohol and placed in $90 \mathrm{~mm}$ Petri dishes on three filter paper discs moistened with sterile distilled water with 5 lesions per Petri dish. The lesions were incubated at $22^{\circ} \mathrm{C}$ under continuous fluorescent lighting. Lesions were examined using an optical microscope after 4 days and conidia were taken with a capillary tube and placed on PSA media (Potato Sucrose Agar: $200 \mathrm{~g}$ potato, $20 \mathrm{~g}$ sucrose, $15 \mathrm{~g}$ Agar-agar, and $1000 \mathrm{ml}$ distilled water) and incubated at $28^{\circ} \mathrm{C}$ to determine the pathogen.

Three plants of Punica granatum L. 'Nana' (plant I: 252 total healthy leaves; plant II: 327 total healthy leaves; plant III: 349 total healthy leaves) were maintained in a greenhouse at 17 $25^{\circ} \mathrm{C}$ (April 2009). These plants were inoculated by spraying with $60 \mathrm{ml}$ of a conidial suspension containing $10^{5}$ conidia $\mathrm{ml}^{-1}$ of fungus. The conidia concentration was adjusted with distilled water, containing $0.02 \%$ of Tween 20 and $1 \%$ gelatin. The control plants were inoculated with distilled water containing Tween 20 and gelatin.

The inoculated plants were kept covered for $48 \mathrm{~h}$ with black bags and then moved to a greenhouse. The test was repeated twice and the same fungus was consistently re-isolated from these lesions. The notation of results was made seven days after inoculation and during one month. The diseased foliar surface $(\%)$ was scored according to the scale of Notteghem et al. (1980).

The conidia production (conidia $\mathrm{cm}^{-2}$ ) of fungus on the infected pomegranate leaves was estimated according to the technique of Hill and Nelson (1983). One month after inoculation, the leaves with lesions were harvested from the inoculated plants, cut into pieces of $1 \mathrm{~cm}^{2}$ and placed in $90 \mathrm{~mm}$ Petri dishes on three filter paper discs moistened with sterile distilled water. The dishes were incubated from 48 to 72 hours at $22^{\circ} \mathrm{C}$ un-
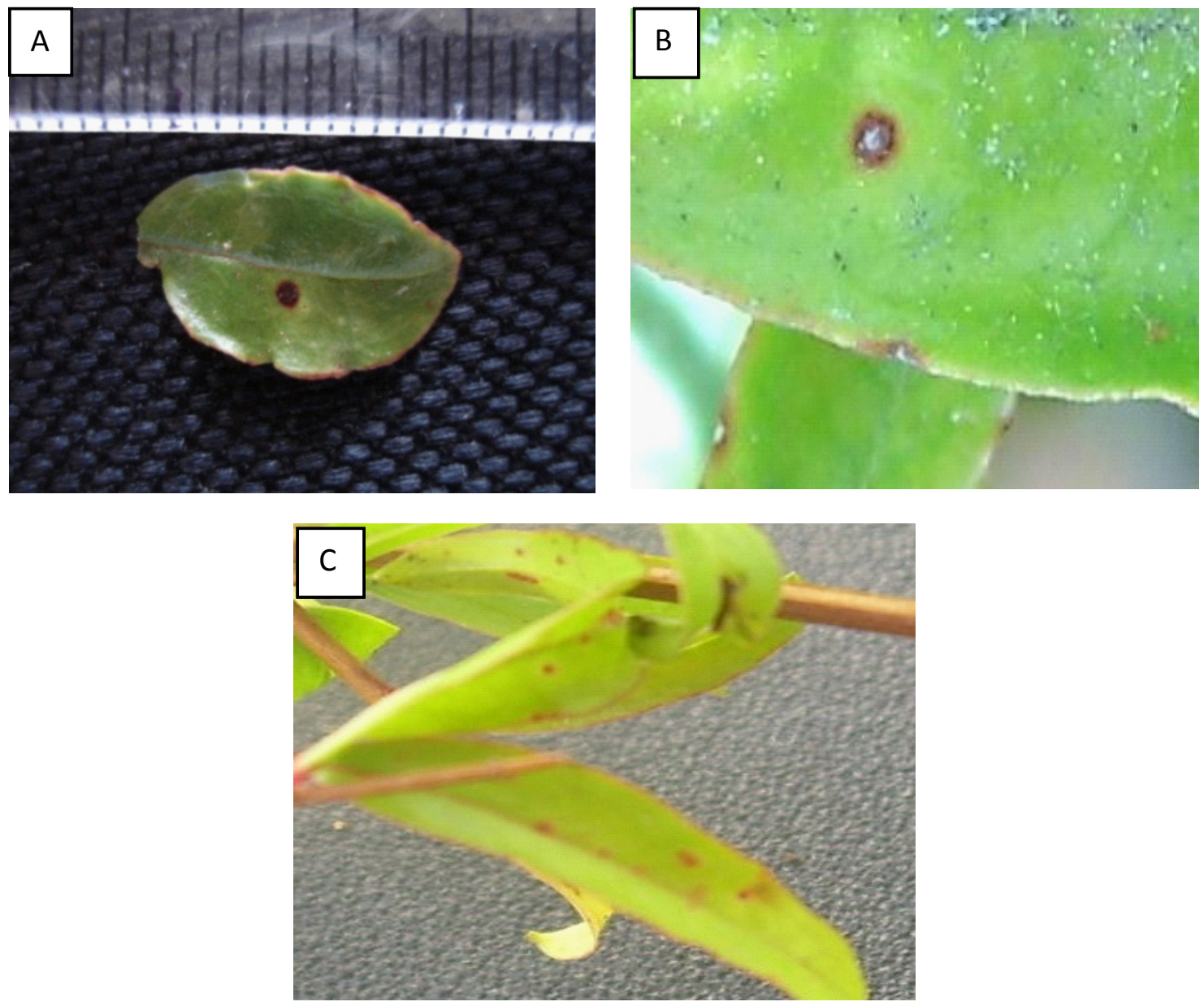

Fig. 1. Foliar symptoms of Bipolaris spicifera infection on Pomegranate plants (Punica graminum L. 'Nana') in nature. (A): dark brown circular lesions; $(B)$ lesion surrounded by a border of dark purple color; $(C)$ : lesions are sometimes numerous. 
der continuous fluorescent lighting. Then, each fragment was placed in a test tube containing $1 \mathrm{ml}$ of sterile distilled water and agitated by a vortex mixer for $2 \mathrm{~min}$. The conidia of the pathogen were counted using a Malassez slide under an optical microscope at magnification $\times 100$ with three counting of each sample.

\section{Results and Discussion}

On PSA, the monospore culture of the fungus isolated was black olive, dark inside, becoming clearer toward the periphery. The conidia were brown, 3 septates, elliptical often cylindrical (16.75 \pm 4$) \mu \mathrm{m}$ long, $(8.25 \pm 2) \mu \mathrm{m}$ wide, rounded at the ends, each with an evident hilum (Figure 2). The conidiophores were erected, unbranched, partitioned, 4-8 $\mu \mathrm{m}$ wide and geniculated. Based on the morphological description (Ellis, 1971), the fungus was identified as Bipolaris spicifera (Bainier) Subram (1971).

Symptoms on leaves of Punica granatum L. 'Nana' appeared seven days after inoculation by $B$. spicifera and the necrotic lesions were identical to that observed in nature (Figure 3 ). The tested plants of $P$. granatum L. 'Nana', all showed sensitivity relative to $B$. spicifera. Between the $7^{\text {th }}$ and $30^{\text {th }}$ day after inoculation, the amount of disease increased with time. The diseased foliar surface of inoculated plants was $0.5 \%$ on the $7^{\text {th }}$ day and increased to $37.5 \%$ on the $30^{\text {th }}$ day pot inoculation (DPI). The total number of leaves with symptoms increased from 10 on the $7^{\text {th }}$ day to 78 on the $30^{\text {th }}$. Bipolaris spicifera was also able to produce conidia on the lesions of $P$. granatum L. "Nana'plants with an average of $0.81 \times 10^{5}$ spore $\mathrm{cm}^{-2}$.

Bipolaris spicifera isolated from 77 host plants, from air and soil (Ellis, 1971). In Morocco, this pathogen was isolated for the first time from foliar lesions of Oryza sativa (Ennaffah et al., 1997), foliar lesions of Hibiscus rosa-sinensis (Meddah et al., 2007) and from watermelon (El Mhadri et al., 2009). This fungus was also isolated from Chloris verticillata, Eragrostis cilianensis and Paspalum leave (Roane and Roane, 1996, 1997); Cynodon
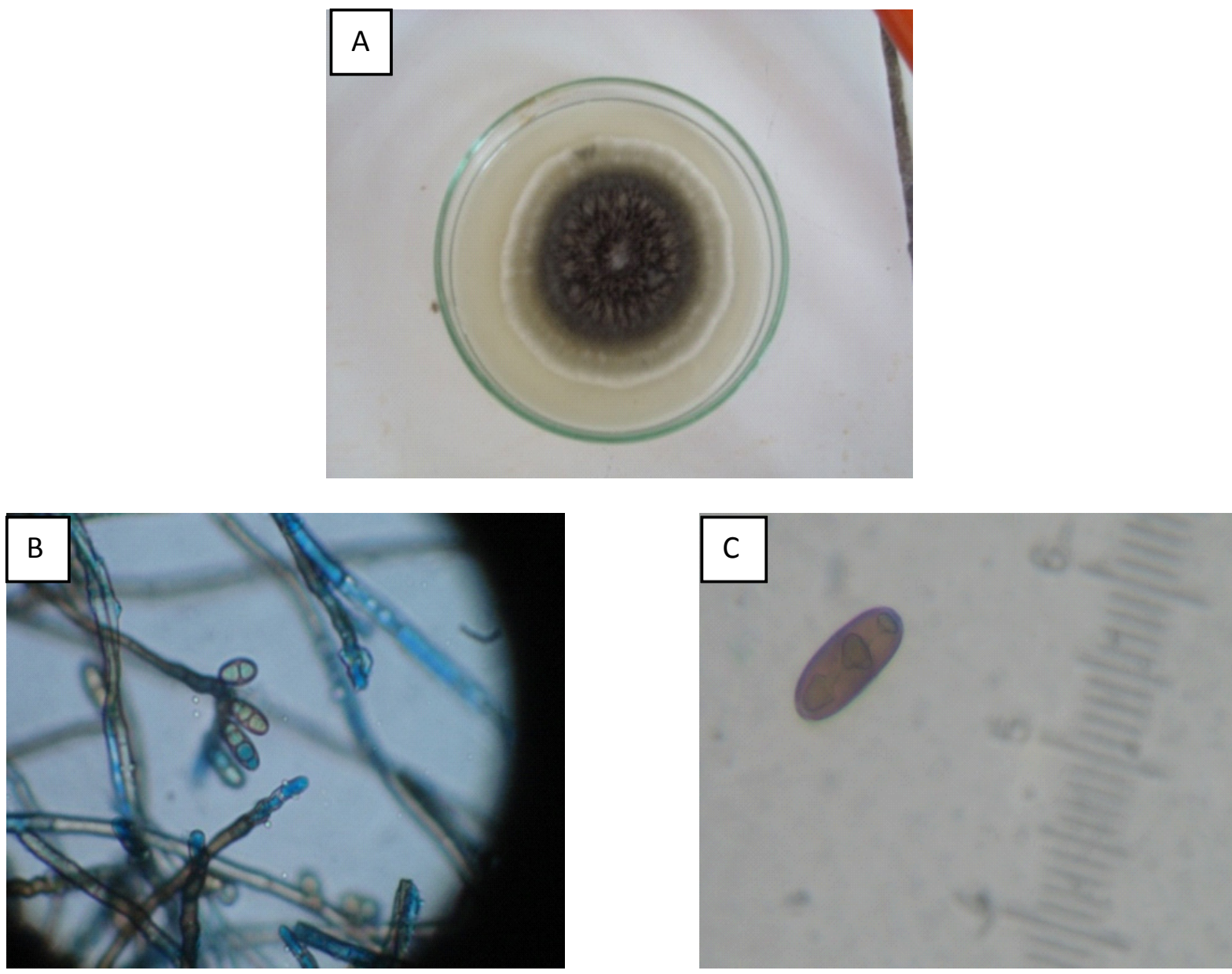

Fig. 2. Colonies (A), Conidiophore (B) and conidia (C) of Bipolaris spicifera isolated from Punica granatum L. 'Nana' and cultivated on PSA medium. 

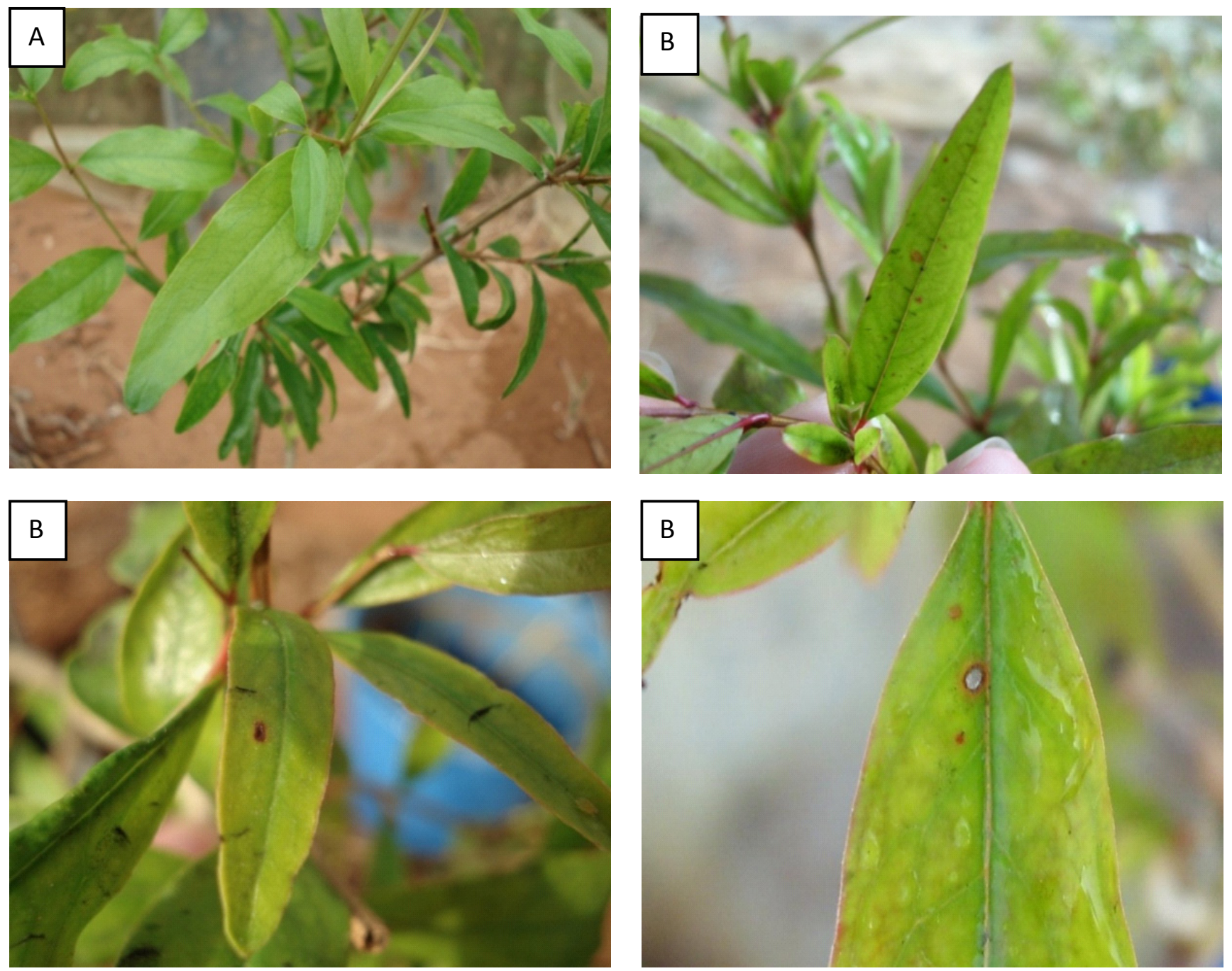

Fig. 3. Lesions developed on pomegranate leaves after artificial inoculation by Bipolaris spicifera. (A): control plant; (B): inoculated plant.

dactylon and Deschampsia flexuosa (Roane, 2004, 2009); Avena sativa, Hordeum vulgare, Secale cerea, and Triticum aestivum (Cook and Dubé, 1989); Oryza sativa, Phaseolus vulgaris, Sorghum bicolor, and from Zea mays (Mendes et al., 1998). Moreover, Bipolaris spicifera was isolated from Setaria glauca and Sorghum halepense (Pratt, 2006); Arachis hypogaea (Pourabdollah and Ershad, 1997); Commelina benghalensis (Caretta et al., 1999); Pistacia vera (Chen et al., 2002); Quercus xalapensis (Mena-Portales et al., 1995) and from the soil (Liu and Zhang, 2004).

To our knowledge, this is the first report of necrotic lesions caused by B. spicifera on P. granatum L. 'Nana' in Morocco. The pathogen was a real problem for the aesthetic quality of this ornamental plant.

\section{References}

Caretta G, Piontelli E, Picco AM, Del Frate G (1999) Some filamentous fungi on grassland vegetation from Kenya. Mycopathologia 145: 155-169.

Chen WQ, Ntahimpera N, Morgan DP, Michailides TJ (2002) Mycoflora of Pistacia vera in the central valley, California. Mycotaxon 83: 147-158.

Cook RP, Dubé AJ (1989) Host-pathogen index of plant diseases in South Australia. South Australian Department of Agriculture 142.

El Mhadri M, Benkirane R, Ouazzani Touhami A, Douira A (2009) Citrullus lanatus, a new host of Bipolaris spicifera in Morocco. Phytopathol Mediterr 48: 291-293.

Ellis MB (1971) Dematiaceous Hyphomycetes, Commonwealth Mycological Institute, Kew, Surrey, England, 608 pp.

Ennaffah B, Bouslim F, Benkirane R, Ouazzani Touhami A, Douira A 
(1997) Helminthosporium spiciferum, foliar parasite of rice in Morocco. Agronomie 17: 299-300.

Hill JP, Nelson RR (1983) Genetic control of two parasiticfitness attribuates of Helminthosporium maydis race T. Phytopathology 73: 455-457.

Jianzhu S, Chunli C, Xiuxin D (2003) In vitro induction of tetraploid in pomegranate (Punica granatum).National Key Laboratory of Crop Genetic Improvement. Plant Cell Tissue and Organ Culture 75: 241-246.

Liu HM, Zhang TY (2004) A preliminary report of soil dematiaceous hyphomycetes from the Yellow River Delta I. Mycosystema 23: 338344.

Meddah N, Ouazzani Touhami A, Douira A (2007) L'Hibiscus rosa-sinensis, un nouvel hôte pour le Cochliobolus spicifer et le Setosphaeria rostrata. Phytoprotection $88: 57-60$.

Mena-Portales J, Heredia-Abarca G, Mercado-Sierra A (1995) Species of Bipolaris and Curvularia on leaves of Quercus and Liquidambar from the state of Veracruz, Mexico. Revista Mex Micol 11: 109-121.

Mendes MAS, da Silva, VL, Dianese JC (1998) Fungos em Plants no
Brasil. Embrapa SPI/Embrapa-Cenargen, Brasilia. 555 pp.

Notteghem JL, Andriatompo GM, Chatel M, Dechanet R (1980) Techniques utilisées pour la sélection de variétés de riz possédant la résistance horizontale à la pyriculariose. Ann Phytopathol 12: 199266.

Pratt RG (2006) Johnsongrass, yellow foxtail, and broadleaf signalgrass as new hosts for six species of Bipolaris, Curvularia, and Exserohilum pathogenic to Bermudagrass. Plant Disease 90: 528.

Pourabdollah S, Ershad D (1997) An investigation on mycoflora of peanut seeds in Iran. Iran J Plant Pathol 33: 64-68.

Roane CW, and Roane MK (1996) Graminicolous Fungi of Virginia: Fungi associated with genera Aegilops to Digitaria. Virginia J Science 47: 197-224.

Roane CW (2009) Graminicolous fungi of Virginia: fungi in collections 2004-2007. Virginia J Science 60: 13-50.

Roane CW (2004) Graminicolous Fungi of Virginia: Fungi in Collections 1995 - 2003. Virginia J Science 55: 139-157.

Roane CW, Roane MK (1997) Graminicolous Fungi of Virginia: Fungi associated with genera Echinochloa to Zizania. Virginia J Science 48: $11-46$. 